\title{
Genetic Influence on Serum IgD Levels
}

\author{
SOK K. LEE, JULIUS D. METRAKOS, KOUICHI R. TANAKA, AND DOUGLAS C. HEINER \\ Departments of Pediatrics (S. K. L., D. C. H.) and Medicine (K. R. T.), Harbor/UCLA Medical Center, UCLA \\ School of Medicine, Torrance, California, USA and Biology Department, McGill University (J. D. M.), Montreal,
} Quebec, Canada

\section{Summary}

In order to better understand the factors determining serum levels of IgD, total serum IgD and IgE were studied in 23 nonallergic twin pairs, consisting of 16 monozygotic $(\mathrm{Mz})$ and 7 samesex dizygotic (Dz) pairs. Both immunoglobulins were measured by a paper disc solid phase radioimmunoassay, sensitive to $1 \mathrm{ug} / \mathrm{dl}$ of IgD and $1 \mathrm{I} . \mathrm{U} . / \mathrm{ml}$ of IgE. Also studied were 10 paired sera taken at different times from $\mathbf{1 0}$ healthy subjects of similar mean age to the twins and 21 randomly paired sera from unrelated subjects.

The intrapair variance of both serum $\mathrm{IgD}$ and serum $\mathrm{IgE}$ levels were significantly less in $\mathrm{Mz}$ than in $\mathrm{Dz}$ twins $(P<0.05)$. Thus, there appears to be a genetic influence over serum IgD levels, probably to a similar degree to that previously shown to exist for serum IgE levels. Heritability was calculated to be 0.759 for IgD and 0.697 for IgE. Also, the intraclass correlation coefficient $\left(r_{I}\right)$ for IgD in monozygotic twin pairs was $0.9370(P<0.0001)$ and for IgE was $0.8602(P<0.001)$. It appears likely that the number of genetic loci controlling serum IgD levels is similar to, or less than, the number controlling serum IgE levels because the random pair/ Dz pair variance ratio was lower for IgD than for IgE.

\section{Speculation}

Because serum IgD can now be measured accurately in all normal subjects, including newborn infants, it should be possible to determine not only the effect of heredity on serum levels but also the effect of specific diseases, infections, antigen exposures, growth, changes in the levels of other immunoglobulins, immunosuppressive agents, and other environmental influences. This will increase the understanding of the immunobiologic role of $\operatorname{IgD}$, and will also facilitate interpretation of measurements of specific serum IgD antibodies and of cell surface IgD.

Genetic control of immune responses has been observed in several situations and has been particularly well studied in inbred strains of mice $(4,6)$. Susceptibility to specific infections agents is known to vary in different species and strains of animals, and strain specific susceptibility to oncogenic viruses is well recognized $(8,16)$. Hereditary disorders of immunity in man have been reviewed recently (29).

Measurement of the serum immunoglobulin levels in human subjects is an important part of the evaluation of the total immune system. Serum immunoglobin levels have been found to be under genetic control by a number of investigators $(2,3,12,18,20,22$, $25)$. IgD was discovered in 1965 by Rowe and Fahey (26) and its chemical characteristics have been studied in some detail (13). However, its biologic role is the least well understood of the five major immunoglobulins. In order to better understand the regulatory mechanisms controlling serum IgD levels, and to compare the heritability of IgD with that of another immunoglobulin, IgE, serum levels of both were studied in a group of twins. To the authors' knowledge, this is the first study of serum IgD levels in twins by a sensitive radioimmunoassay capable of measuring serum levels accurately in subjects of any age.

\section{MATERIALS AND METHODS}

\section{MATERIALS}

Total IgD and IgE levels were studied in 23 nonallergic twin pairs consisting of 16 monozygotic twin pairs (10 male and 6 female) and 7 same-sex dizygotic pairs ( 3 male and 4 female) Serum samples were obtained from each twin pair, $0.05 \%$ sodium azide was added as a preservative and $0.01 \mathrm{M}$ epsilon aminocaproic acid was added as a deterrent to enzymatic degradation o IgD. The specimens were immediately frozen and kept at $-20^{\circ} \mathrm{C}$ until the experiment was performed.

For controls, paired sera were obtained from 10 healthy subject: at $1 \mathrm{wk}-3 \mathrm{yr}$ intervals (same person pairs) and sera from healthy subjects were randomly paired to make 21 different pairs (randon pairs). Controls were age-matched to the twin subjects whose sers were already in the deep freeze (Table 1).

In order to evaluate the technical reproducibility of this radioim munoassay, 13 sera were measured a second time on a differen day (mean measurement error).

\section{ZYGOSITY DETERMINATION}

Blood from each member of the twin pairs was typed for 2 different erythrocyte antigens by one of the authors (J. M.).

Zygosity was determined as: 1) Mz, if all types were identica 2) $\mathrm{Dz}$, when one or more types were nonidentical.

\section{METHODS}

Serum $\operatorname{IgD}$ and $\operatorname{IgE}$ were measured, using a modification of th paper disc immunoassay described by Ceska et al. (7). Details o the procedures used to isolate $\mathrm{IgE}$, prepare the $\mathrm{Fc}$ fragmen immunize rabbits, absorb the antisera, prepare immunosorbents isolate anti IgE, prepare antibody-coated discs, and perform Ig. assays have been described elsewhere (21).

The major differences in the preparation of materials for th two assays were the shorter period of digestion of $\mathrm{IgD}$ with papai ( $15 \mathrm{~min}$ as opposed to $2 \mathrm{hr}$ for $\mathrm{IgE}$ ) and the use of $6 \mathrm{M}$ urea rathe than $\mathrm{pH} 2.5$ glycine-HCL for eluting anti-IgD from the D-mye loma immunosorbent. Ten millimolar epsilon amino caproic aci was added to all reagents during the preparation of anti $\operatorname{IgD}(\mathrm{F}$ and during all radioimmunoassays.

In brief, the assays were performed as follows: 1) A cyanoge bromide-activated cellulose disc, to which was covalently couple monospecific rabbit anti-IgD or anti-IgE, was incubated overnigh with each serum sample at room temperature. 2) After washin the disc three times, purified and $\mathrm{I}^{125}$-radiolabeled anti-IgD 0 anti-IgE was added. The disc was again incubated overnigh during which time the total radioactivity of each tube was deter mined in a Beckman Biogamma II counter. 3) Discs were the 
Table 1. Population samples tested

\begin{tabular}{lcr} 
& $\begin{array}{c}\text { Sample } \\
\text { Size }\end{array}$ & $\begin{array}{c}\text { Mean age }(\mathrm{yr}) \\
\pm \mathrm{SD}\end{array}$ \\
\hline Mz twin & 16 & $12.2 \pm 7.3$ \\
Same-sex Dz twin & 7 & $7.3 \pm 1.1$ \\
Same person pair (SP) & 10 & $9.7 \pm 3.7$ \\
Random pair (RP) & 21 & $11.8 \pm 6.1$ \\
Same serum tested different day & 13 & \\
\hline
\end{tabular}

thoroughly washed with $0.1 \%$ tween 20 in saline and twice with $0.9 \%$ saline solution alone. 4) Bound counts were determined. The greater the serum concentration of $\operatorname{IgD}$ or $\operatorname{IgE}$, the more radiolabeled anti-IgD or anti-IgE was bound to the corresponding disc. Tests were performed in duplicate and the mean was used for statistical analysis. Even though there was no detectable cross reactivity between the two systems by extensive micro-Ouchterony analyses, to evaluate any possibility of cross-reaction between anti-IgD and anti-IgE in the radioimmunoassay, the relationship of the IgD and IgE levels in each serum was plotted on a scatter diagram (Fig. $1 ; r=0.08, \mathrm{P}<0.1$ ).

\section{STATISTICAL ANALYSIS}

All immunoglobulin values were transformed into common logarithms because serum levels in larger populations appear not to have a Gaussian distribution. Statistical analyses were carried out by two methods. The first method was described by Osborne and DeGeorge (24) which is based on a comparison of the variance of the differences between dizygotic twin pairs $(\mathrm{Vdz})$ and monozygotic twin pairs $(\mathrm{Vmz})$.

Mean intrapair variance is defined as $\Sigma \mathrm{x}^{2} / 2 \mathrm{n}$, where $\mathrm{x}$ is the difference between two members of a twin pair and $n$ is the number of twin pairs. The mean measurement error (ME) was calculated in a similar manner. In this case, $n$ equals the number of individual measured twice. The significance of the difference in the variances between categories of these pairs was analyzed by the on-tailed F-test.

Heritability $(\mathrm{H})$ is defined as the relative contribution of heredity (compared to environment) to the total serum immunoglobulin level. This may be written as $\mathrm{H}=\frac{\mathrm{Vdz}-\mathrm{Vmz}}{\mathrm{Vdz}}(15,23,24)$.

In addition, in order to analyze the data by a second technique, the intraclass correlation coefficient $\left(\mathrm{r}_{\mathrm{I}}\right)$ was calculated for both $\mathrm{Mz}$ and Dz twins as described by Jensen (17) and Zar (37). The general formula for this coefficient is $R_{I}=$ $\frac{\text { groups MS - error MS }}{\text { groups MS + error MS }}$. The values for $\mathrm{R}_{\mathrm{I}}$ can perhaps be better groups MS + error MS
understood by considering that if the levels were identical within each pair, the coefficient would be 1.0. On the other hand, if the intrapair variability greatly exceeded the interpair variability, $\mathrm{r}_{\mathrm{I}}$ would approach -1.0 .

All statistical analyses were performed on a Monroe Model 1869 computer.

\section{RESULTS}

A scatter diagram of the individual values after logarithmic transformation is shown in Figure 2. Mean intrapair differences in serum $\operatorname{IgD}$ and serum IgE levels are least in the same person pairs, followed by $\mathrm{Mz}$ twin pairs, then $\mathrm{Dz}$ pairs. The greatest difference is found in the serum pairs selected from a table of random numbers. The same in general holds true for serum IgE.

The $\mathrm{F}$ tests and variances of the twin groups are shown in Table 2. Mean measurement error for IgD levels, which indicates variance in the assay itself, was smaller than the intrapair variance in the $\mathrm{Mz}$ twin which in turn was smaller than in Dz twins. Variance of random pairs was the greatest of all categories. Same person pairs had similar variability to that of Mz twins. Similar variance differences were found in the case of IgE levels.

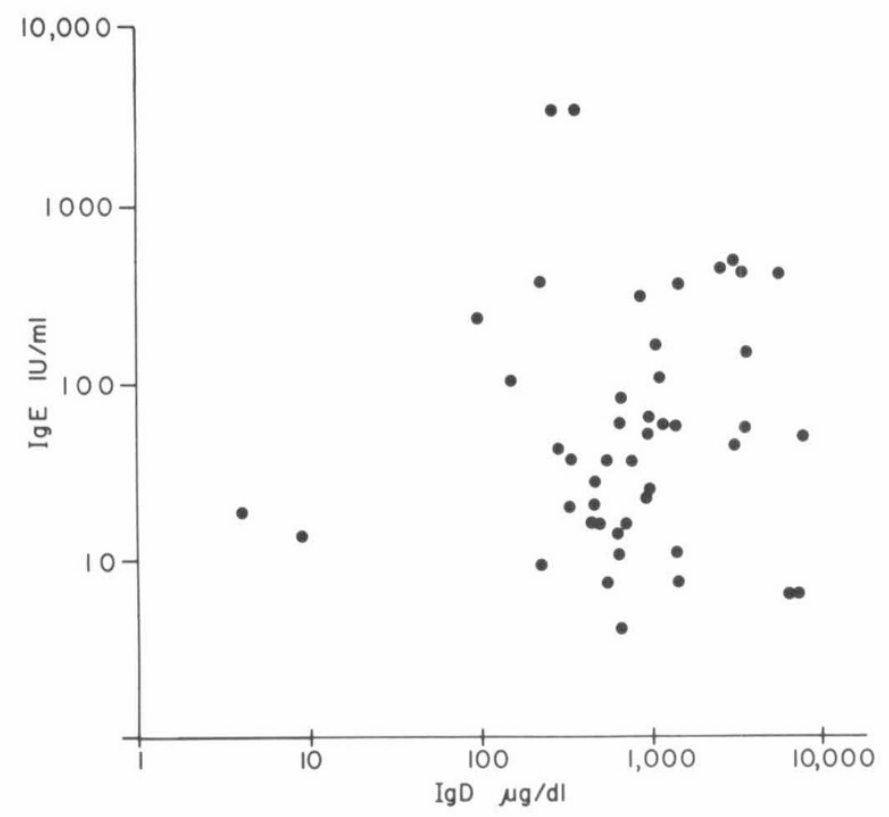

Fig. 1. Scatter diagram if $\operatorname{IgD}$ and $\operatorname{IgE}$ levels in each specimen from the twins studied. There is no discernible relationship between IgD and IgE levels $(r=0.08, \mathrm{P}>0.1)$.

The F-ratio of Mz pairs over mean measurement error was 5.50 in the case of $\operatorname{IgD}$, and 8.40 in the case of $\operatorname{IgE}(P<0.01)$. This suggests that the radioimmunoassay employed was sufficiently accurate to detect the effect of nongenetic influences in the $\mathrm{Mz}$ twin pairs.

There was a significant difference in variance between $\mathrm{Mz}$ pairs and $\mathrm{Dz}$ pairs with $P<0.05$ for both $\operatorname{IgD}$ and $\operatorname{IgE}$. When same person pairs were compared to measurement error, a significant difference was seen between sera drawn from the same person on different days and a single serum sample tested on different days, demonstrating that measurable variations in the serum levels of both $\mathrm{IgD}$ and $\mathrm{IgE}$ are common over the course of weeks or months. The ratio of random pair variability over $\mathrm{Dz}$ or $\mathrm{Mz}$ twinpair variability was highly significant in the case of IgE due to the great variability in random pairs. There were similar significances for the ratios of $\mathrm{IgD}$ and $\mathrm{IgE}$ except in the comparison of random pairs over $\mathrm{Dz}$ pairs for IgD which did not attain significance by the $\mathrm{F}$ test. The heritability was 0.759 for $\operatorname{IgD}$ and 0.697 for $\operatorname{IgE}$.

The intraclass correlation coefficient $\left(\mathrm{r}_{\mathrm{I}}\right)$ of $\mathrm{IgD}$ and $\mathrm{IgE}$ levels in $\mathrm{Mz}$ twin pairs were $0.9370(P<0.0001)$ and $0.8602(P<0.001)$, respectively. In Dz twin pairs, $\mathrm{r}_{\mathrm{I}}$ was $0.1068(P<0.3)$ for $\operatorname{IgD}$ and $0.054(P<0.4)$ for IgE.

\section{DISCUSSION}

The biologic role of $\operatorname{IgD}$ is not well understood at the present time. An indication of its possible functional role has come from recent demonstrations that $\mathrm{IgD}$ is present on the surface of a high proportion of lymphocytes. This is particularly striking in the neonatal period when serum IgD levels are very low, and in patients with chronic lymphocytic leukemia $(1,19,27,30)$.

Vitetta et al. $(34,35)$ studying murine B lymphocytes, suggested that surface IgD may act as an important receptor in triggering B lymphocyte maturation.

Even less is known concerning the function of circulating antibodies of the IgD class. Although several investigators have shown that IgD antibodies to specific antigets are detectable in selected sera, they have seldom been the predominant class of antibody, and no unique role such as opsonization, complement activation, or cytotrophic activity has been demonstrated $(10,14$, $28,33,36)$.

Serum IgD levels at birth are very low, but measureable, in all infants using the radioimmunoassay employed in this study (32). 


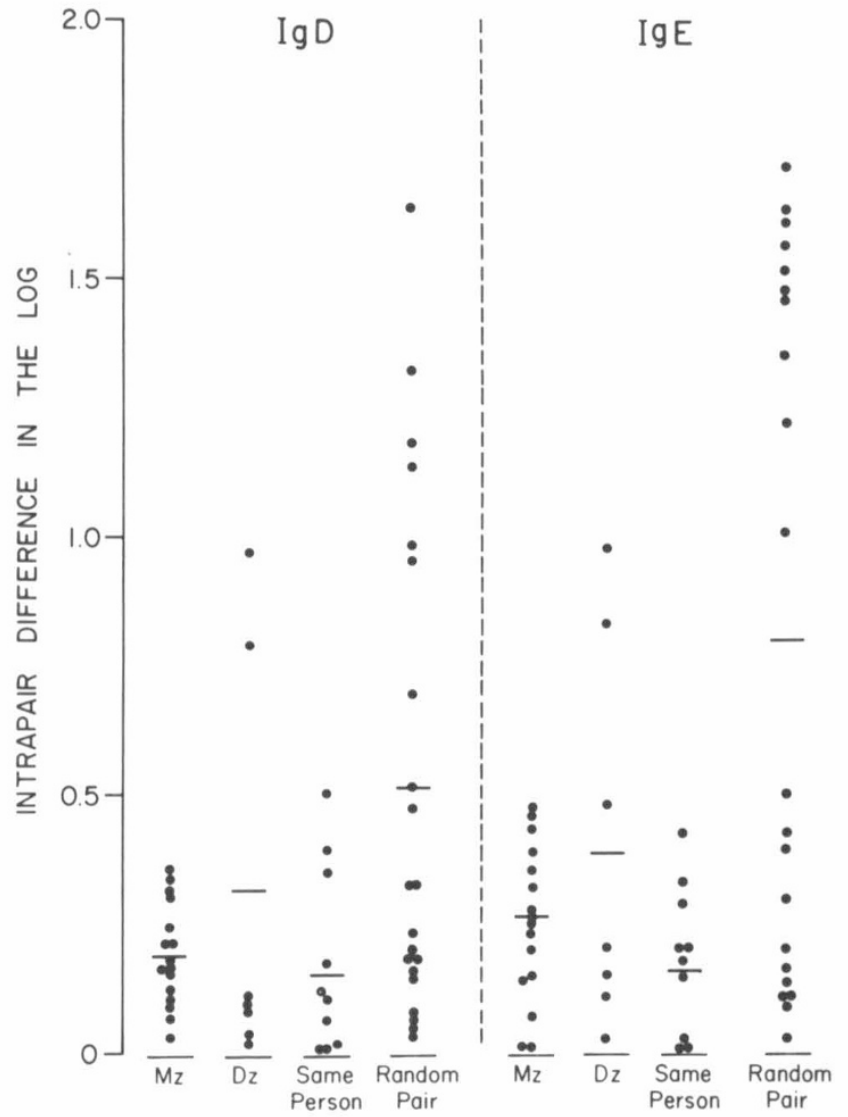

Fig. 2. Scatter diagram of intrapair differences in plotting the common logarithms. The bar depicts the geometric mean of each group.

Table 2. Statistical analysis of data

\begin{tabular}{lllrl}
\hline \multicolumn{1}{c}{ Group } & $\begin{array}{l}\text { Vari- } \\
\text { ance }\end{array}$ & \multicolumn{1}{c}{ Ratio } & F-value & \multicolumn{1}{c}{$P$} \\
\hline IgD & & & & \\
Mean meas. error & 0.005 & & & \\
Mz pairs & 0.3 & Mz/MME & 5.50 & $<0.01$ \\
Dz pairs & 0.17 & Dz/Mz & 4.14 & $<0.05$ \\
Same person & 0.03 & SP/MME & 5.88 & $<0.01$ \\
Random pair & 0.25 & RP/Mz & 1.47 & N.S. ${ }^{1}$ \\
& & RP/Mz & 8.90 & $<0.005$ \\
& & & & \\
IgE & & & & \\
Mean meas. error & 0.005 & & & \\
Mz pairs & 0.04 & Mz/MME & 8.40 & $<0.01$ \\
Dz pairs & 0.14 & Dz/Mz & 3.30 & $<0.05$ \\
Same person & 0.03 & SP/MME & 4.80 & $<0.05$ \\
Random pair & 0.54 & RP/Dz & 3.86 & $<0.05$ \\
& & RP/Mz & 12.74 & $<0.0001$ \\
\hline
\end{tabular}

${ }^{1}$ Not significant.

Normal newborns have a mean level of approximately $8.0 \mathrm{ug} / \mathrm{dl}$. The mean level increases gradually thereafter until about $6 \mathrm{yr}$ of age when the adult mean level of $2,000 \mathrm{ug} / \mathrm{dl}$ is reached. The range found in healthy adults varies between $20-30,000 \mathrm{ug} / \mathrm{dl}$. Total serum IgD levels in a particular individual vary relatively little from time to time within this wide normal range, but a 2- or 3-fold fluctuation over a period of months is not uncommon. The authors have observed that changes in the level of total serum IgD frequently occur in an opposite direction to changes in total serum $\operatorname{IgE}(31)$. Terantino (33) has reported deposits of $\mathrm{IgD}$ in the renal biopsies in chronic nephropathies, using immunofluorescence techniques. He suggested a participant role for IgD antibodies in the etiology of these nephropathies. Boudart et al., interestingly, have proposed a protective role for serum IgD antibodies.
Serum IgD has been detected only in humans, while B-lymphocyte surface membrane $\operatorname{IgD}$ has been found in monkeys, mice, rats, and probably other mammals and fowl, as well as in humans. This suggests that IgD may play its major role as a cell membrane receptor rather than as a serum antibody. However, sensitive tests to measure total serum $\operatorname{IgD}$ and $\mathrm{IgD}$ antibodies have not been developed for species other than man. Hence, final judgment cannot yet be made concerning serum $\operatorname{IgD}$ in other species. The interrelationships between serum and cell-surface $\operatorname{IgD}$ in man need further study as do the interrelations between $\operatorname{IgD}$ and other classes of immunoglobulins.

In 1968, Rowe et al. (25) studied the immunoglobulin levels of twins by radial immunodiffusion and showed that there was a genetic influence on levels of $\operatorname{IgG}, \operatorname{IgA}$ and $\operatorname{IgM}$ in adolescents less than $21 \mathrm{yr}$ of age. Allansmith et al. (2) and Kalff and Hijams (18) also reported that there was a genetic influence over the levels of $\operatorname{IgG}, \operatorname{IgA}$, IgD and IgM as measured by radial immunodiffusion.

The current study is the first to assess the genetic influence of IgD levels in twins employing a method capable of measuring IgD in all healthy subjects. This is important because there is a wide range of normal IgD levels and accurate measurements are not possible by radial immunodiffusion in about $40 \%$ of children. The radioimmunoassay used was sufficiently sensitive to show variability in serum IgD and $\mathrm{IgE}$ levels in sera from the same person drawn at different times (Table 2).

The findings of the authors in regard to $\mathrm{IgE}$ are in agreement with those of Hamburger et al. (12) who found an hereditary influence on the regulation of serum IgE levels (heritability index 0.8393 ). The present study showed a heritability of 0.697 for IgE. The somewhat lower index of heritability in this study may have been due to the lesser mean age of the Dz twins $(7.3 \mathrm{yr})$ than of the $\mathrm{Mz}$ twins (12.2 yr) studied. Hamburger et al. (12) did not indicate the age relationships between his twin groups.

Statistical analysis of intraclass correlations indicates a marked similarity of serum levels within the $\mathrm{Mz}$ twin pairs where genetic differences are minimal. This is true for both serum $\operatorname{IgD}\left(R_{I}=\right.$ $0.9370)$ and serum $\operatorname{IgE}\left(r_{i}=0.8602\right)$.

It is realized that the number of $\mathrm{Dz}$ twin pairs $(\mathrm{N}=7)$ in the current study is rather small and the intrapair differences in serum $\mathrm{IgD}$ of two out of the seven $\mathrm{Dz}$ pairs are disproportionately large. Nevertheless, in the statistical analysis by F-test, the sample size is taken into account $(P<0.05)$. Because of this and because the sampling was unselected in $\mathrm{Dz}$ as well as $\mathrm{Mz}$, it appears likely that true genetic influence on serum IgD levels exists. These results need to be confirmed by studies using larger sample sizes.

The mode of inheritance of serum IgD levels is still not certain. Dunnette et al. (10) suggested a monogenic mechanism. Furthermore, they (11) studied pedigrees of families with lower serum IgD which suggested an autosomal recessive inheritance. This study indicates that: 1) Intrapair variances of both serum IgD and serum IgE levels in $\mathrm{Mz}$ twins are significantly less than in $\mathrm{Dz}$ twins $(P<0.05) .2)$ Serum IgD levels are under genetic influence as evidenced by a heritability of 0.759 . This is similar to the genetic influence observed for serum IgE levels. 3) The number of genetic loci controlling IgD levels is probably similar to the number controlling IgE levels. The latter tentative conclusion is reached because it has been observed that when the genetic component of variability involves only one or a very few independent loci there is a decrease in the random intrapair variance relative to the $\mathrm{Dz}$ intrapair variance (decreased $\mathrm{RP} / \mathrm{Dz}$ ratio) (24). When many independent genetic loci are involved, there is an increased random intrapair variance with a tendency toward decreased $\mathrm{Dz}$ intrapair variance, and the $\mathrm{RP} / \mathrm{Dz}$ ratio is increased. Because in this study the $\mathrm{RP} / \mathrm{Dz}$ variance ratio was lower in the case of $\operatorname{IgD}$ than in the case of $\operatorname{IgE}$, it appears likely that the number of independent genetic loci controlling serum IgD levels is similar to or less than the number controlling serum IgE levels.

\section{REFERENCES AND NOTES}

1. Abney, E. P., and Parkhouse, R. M. E.: Candidate for immunoglobulin D present in murine B lymphocytes. Nature, 252: 600 (1974).

2. Allansmith, M., McClellan, B., and Butterworth, M.: The influence of heredity 
and environment on human immunoglobulin levels. J. Immunol., 102: 1504 (1969).

3. Bazoral, M., Orgel, N. A., and Hamburger, R. N.: IgE levels in normal infants and mothers and an inheritance hypothesis. J. Immunol. 107: 794 (1971).

4. Benacerraf, B., and Katz, D. H.: The histocompatibility-linked immune response genes. Adv. Can. Res., 21: 121 (1975).

5. Boudart, D., Guimeretiere, L., Guimeretiere, J.: Role of IgD in "IN" protective system. Pathol. Biol., 25: 185 (1977).

6. Biozzi, C., Stiffel, C., Mouton, D., Bouthillier, Y., and Decreusefond, C.: Cytodynamics of the immune response in two lines of mice genetically selected for "high" and "low" antibody synthesis. J. Expl. Med., 135: 1071 (1972).

7. Ceska, M., Eriksson, R., and Varga, J. M.: Radioimmunosorbent assay of allergens. J. Allergy Clin. Immunol., 44: 1 (1971).

8. Chang, S. S., Hildemann, W. H., and Rasmussen, A. F., Jr.: Immunogenetic aspects of polyoma virus susceptibility in mice. J. Natl. Can. Inst., 40: 363 (1968).

9. Devey, M., Sanderson, S. J., Carter, D., and Coombs, R. R. A.: IgD antibody to insulin. Lancet, 2: 1280 (1970).

0. Dunnette, S. L., Gleich, G. J., Miller, R. D. and Kyle, R. A.: Measurement of IgD by a double antibody radioimmunoassay: demonstration of an apparent trimodial distribution of IgD levels in normal human sera. J. Immunol., 119: 1727 (1977).

11. Dunnette, S. L., Gleich, G. J., and Weinshilboum, R. M.: Inheritance of low serum immunoglobulin D. J. Clin. Invest., 2: 248 (1978).

12. Hamburger, R. N., Orgel, H. A., and Bazoral, M.: Genetics of human serum IgE levels. In: L. Goodfriend, A. M. Sehon, and R. P. Orange: Mechanism of allergy reagin-mediated hypersensitivity. (Marcel Dekker, Inc. New York, 1973) pp. 131-139

13. Heiner, D. C.: Biological, immunological, and physiochemical properties of D immunoglobulin (IgD). Ph.D. thesis, May, 1969, McGill University, Montreal, 204 pages (Dissertation Abstr. Intern. XXX No. 11, 1970).

14. Heiner, D. C., and Rose, B.: A study of antibody response by radioimmunodiffusion with demonstration of D antigen binding activity in four sera. J. Immunol., 104: 691 (1970).

15. Holzinger, K.: The relative effect of nature and nature influences on twin differences. J. Educ. Psychol., 20: 241 (1929).

16. Gowen, J. W.: Genetic effects in non-specific resistance to infectious disease. Bact. Rev, 24: 192 (1960).

17. Jensen, A. R.: Kinship Correlations Reported by Sir Cyril Burt. Behav. Genet., 4: 1 (1974).

18. Kalff, M. W., and Hijams, W.: Serum immunoglobulin levels in twins. Clin. Exp. Immunol., 5: 469 (1969).

19. Kubo, R. T., Grey, H. M., and Pirofsky, B.: IgD; a major immunoglobulin on the surface of lymphocytes from the patient with chronic lymphocytic leukemia. J. Immunol., 112: 1952 (1974).

20. Lee, S. K., and Heiner, D. C.: Genetic control of serum IgD. Proceedings American Congress of Allergy and Immunology, New York City (1977).

21. Lee, W. Y., and Heiner, D. C.: Preparation of rabbit anti-IgE for use in radioimmunoassays of total IgE and specific IgE antibodies. J. Immunol. Methods, 45: 1 (1977).

22. March, D. G., Bias, W. B., and Ishizaka, K.: Genetic control of basal serum IgE and its effects on specific reaginic sensitivity. Proc. Nat. Acad. Sci. USA, 71 3588 (1974).

23. Neel, J. V., and Schull, W.: Human heredity. (Chicago, University of Chicago Press, 1954) p. 275.

24. Osborne, R. M., and DeGeorge, L. V.: Genetic basis of morphological variation. (Cambridge, Harvard University Press, 1959) pp. 15-24.

25. Rowe, D. S., Boyle, J. A., and Buchanan, W. W.: Plasma immunoglobulin concentrations in twins. Clin. Exp. Immunol., 3: 233 (1968).

26. Rowe, D. S., and Fahey, J. L.: A New class of human immunoglobulins I. A unique myeloma protein. J. Expl. Med., 121: 171 (1965).

27. Rowe, D. S., Hug, K., Lorni, L., and Pernis, B.: Immunoglobulin D as a lymphocyte receptor. J. Expl. Med., 138: 965 (1973).

28. Schmidt, K., and Mueller-Eckhardt: Antinuclear autoantibodies of IgD class. An analysis of 82 patients. . Z. Immun. Forsch. Bd., 145: 385 (1973).

29. Schuster, J., and Eisen, A. M.: Immunologic deficiency disease. In: S. Freedman, and P. Good: Clinical Immunology (New York, Harper and Row Publishers, 1976) pp. 381-419.

30. Stern, C., and McConnell, I.: IgM and IgD as antigen-binding receptors on the same cell with shared specificity. Eur. J. Immunol., 6: 225 (1976).

31. Tamura, H., Tateno, K., and Heiner, D. C.: Reciprocal relationships between serum levels of IgE and IgD. J. Allergy Clin. Immunol., 61: 178 (1978).

32. Tateno, K., Lee, W. Y., Moriarty, M., Hackett, T. N., and Heiner, D. C.: IgD radioimmunoassay (IDRIA) sensitive to $10 \mathrm{ng} / \mathrm{ml}$. J. Allergy Clin. Immunol. 57: 243 (1976).

33. Terantino, A.: Deposits of $\mathrm{IgD}$ in renal disease. Eur. J. Clin. Immunol., 4: 175 (1974).

34. Vitetta, E. S.: Cell surface immunoglobulin. XI. Appearance of an IgD-like molecule on murine lymphoid cell during ontogeny. J. Exptl. Med., 141: 206 (1975).

35. Vitetta, E. S., and Uhr, J. W.: Immunoglobulin-receptors. Rev. Sci., 189: 964 (1975).

36. Weliky, N., Heiner, D. C., Tamura, H., and Anderson, S.: Tartrazine-specific IgD and IgE antibodies. J. Allergy Clin. Immunol., 61: 190 (1978).

37. Zar, J. H.: In: Biostatistical Analysis (Prentice-Hall, Inc. Englewood Cliffs, NJ, 1974) pp. 246-248.

38. This research was supported by United States Public Health Service grant HD 09327.

39. This study was presented, in part, at the American Congress of Allergy and Immunology, New York City, March 30, 1977.

40. Requests for reprints should be addressed to: S. K. Lee, M.D., Department of Pediatrics, Southern California Permanente Medical Group, 1050 W. Pacific Coast Highway, Harbor City, California 90710, USA.

41. Received for publication July 7, 1978.

42. Accepted for publication January 30, 1979. 